\title{
The value of in vitro cell culture of granulocytes in the detection of Ehrlichia
}

\author{
Valor da cultura celular de granulócito in vitro na detecção de Ehrlichia
}

\section{Alex Mutani ${ }^{1}$ and James Stwart Kaminjolo ${ }^{1}$}

\begin{abstract}
Peripheral blood leukocytes from different animals were isolated from whole blood and maintained in Dulbeco's medium containing homologous serum without antibiotics. After 72 hrs microscopic examination of these cells showed that most animals were infected with Ehrlichia. Observation of thin blood smears from the same animals showed that only two were positive for Ehrlichia. The results of this investigation show that leukocyte culture is superior to the traditional thin blood film method in the detection of Ehrlichia and that asymptomatic carriers are easily detected. The method is inexpensive and does not require specific cell lines although it is necessary to use sterile sera.
\end{abstract}

Key-words: Ehrlichia. Cell Culture. Mononuclear cells.

Resumo Leucócitos do sangue periférico de diferentes animais foram isolados do sangue total e mantidos em meio de Dulbeco, contendo soro homólogo sem antibióticos. Após 72 horas, um exame microscópico destas células mostrou que a maioria dos animais era infectada com Ehrlichia. Observação de esfregacos de sangue dos mesmos animais mostrou que apenas dois eram positivos para Ehrlichia. Os resultados desta pesquisa mostraram que a cultura de leucócitos é superior ao método tradicional de película de sangue na detecção de Ehrlichia, e que portadores assintomáticos são facilmente detectados. O método é de baixo custo e não exige linhas de células específicas, embora seja necessário o uso de soro estéril.

Palavras-chaves: Ehrlichia. Cultura celular. Células mononucleares.

Natural infections of Ehrlichia pose diagnostic problems. In many cases the agents can neither be demonstrated in capillary blood films nor can they be detected in tissue impressions ${ }^{11}$. For many years, diagnosis of ehrlichiosis depended on clinical signs. This method has considerable limitations since several other pathogens may produce similar findings. Detection of the organism in blood films is a time consuming and laborious process, often resulting in false negatives ${ }^{6}$. Although serology has been utilized in the diagnosis of ehrlichiosis, it is often associated with problems such as strain variations ${ }^{5}$ and inter-specific crossreactivity $^{8}{ }^{12}$. Belongia et all showed that serological methods may produce either false negatives due to use of acute sera or false positives from convalescent sera. The polymerase chain reaction is now a method of choice for diagnosis of ehrlichiosis because of its high predictive value $^{9}{ }^{10}$. Unfortunately this method is associated with economic constraints which, in many laboratories with limited resources, would be prohibitive. Since the development of an in vitro method for the cultivation of $E$. canis by Nyindo et $a^{14}$ similar reports have been produced by other workers ${ }^{10111317}$. In all the published reports some pre-requisites for the successful establishment of Ehrlichia in vitro are mentioned. These include the stage of infection of the animal, whether acute or chronic ${ }^{15}$, the presence of specific cell lines ${ }^{101112}$ or the requirement of repeated peritoneal lavage to obtain infected cells ${ }^{17}$. The results of the present investigation show that:

A) in vitro culture of Ehrlichia can be carried out using only the individual host's peripheral blood leukocytes, hence eliminating the requirement for specific cell lines.

B) this method can detect asymptomatic carriers.

\footnotetext{
1. School of Veterinary Medicine, The University of The West Indies, Saint Augustine, Trinidad and Tobago, West Indies. Address to: Dr. Alex Mutani, School of Veterinary Medicine/The University of The West Indies, St. Augustine, Trinidad, West Indies. Tel: 55 1-868-645-2640 Fax: 55 1-868-645-7428.

e-mail:mutani@excite.com

Recebido para publicação em 10/3/2000.
} 


\section{MATERIAL AND METHODS}

Thin blood smears were prepared from six dogs, ten cattle, two horses, and one goat. The animals were of different ages and originated from different areas in Trinidad. Their previous exposure to ixodid ticks was not available. Apart from the dogs, which were brought to the veterinary clinic for various reasons, all other animals were apparently healthy (Table 1 ). The smears were stained with Wrights-Giemsa stain and examined

Table 1 - Species and clinical status of animals tested.

\begin{tabular}{lrlcr}
\hline Species & Nr. tested & Clinical status & \multicolumn{2}{c}{ Nr. positive in using } \\
\cline { 3 - 5 } & & & blood slide & culture \\
\hline Canine & 6 & asymptomatic & 1 & 6 \\
Bovine & 10 & asymptomatic & 1 & 10 \\
Equine & 2 & asymptomatic & 0 & 2 \\
Caprine & 1 & asymptomatic & 0 & 1 \\
\hline
\end{tabular}

under immersion oil. From each animal $7.5 \mathrm{ml}$ of blood was drawn aseptically into sterile monoject heparinized tubes (Sherwood Medical, St. Louis, Missouri, U.S.A.). The tubes were left in a vertical position at room temperature for various times depending on the erythrocyte sedimentation rate of the species (canine: $1 \mathrm{~h}$.; bovine: 24 hr.; equine: $30 \mathrm{~m}$. and caprine: $24 \mathrm{hr}$.) as reported by Benjamin ${ }^{2}$. Thereafter, the plasma and leukocytes were aseptically collected into Leighton tubes, allowing $2 \mathrm{ml}$ per tube. The tubes were incubated at $37^{\circ} \mathrm{C}$ for $48 \mathrm{hr}$ under atmospheric conditions. The plasma was then discarded and the tubes washed with Dulbeco's medium without antibiotics. Two mililitres of Dulbeco's medium containing $20 \%$ homologous serum without antibiotics was then added to each tube. The tubes were subsequently fed with the same medium between 48 and $72 \mathrm{hrs}$. At the end of two and four days post-incubation the cover slips were removed, stained with Wrights-Giemsa stain and examined under immersion oil under a Nikon Optiphot-2 photomicroscope.

\section{RESULTS}

Figure 1 shows the appearance of ehrlichial organisms as seen in bovine peripheral blood smear.

Although blood smears from some animals were negative, (Table 1) results from cell culture revealed that all animals tested were infected with Ehrlichia.

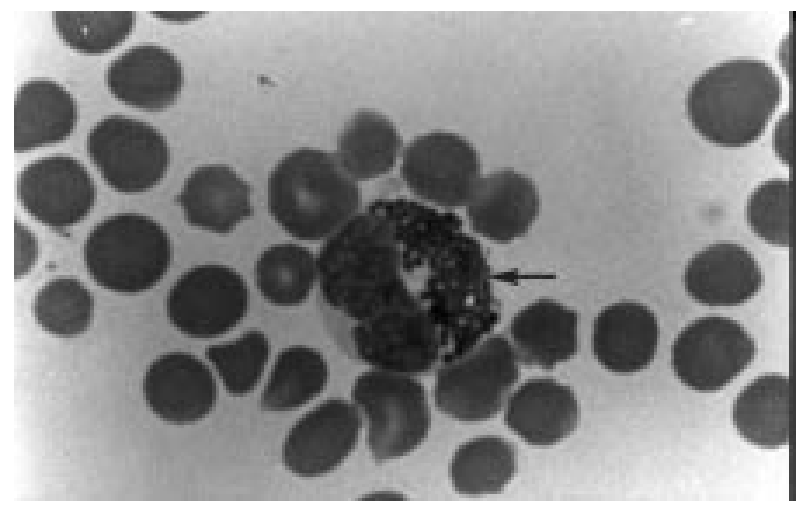

Figure 1 - Bovine peripheral blood mononuclear cell showing monomorphic inclusions (è) -Wrights-Giemsa stain x 1000.

Figure 4 shows a canine mononuclear granulocyte on the fourth day of culture. Several bodies are evident, displacing the host cell's nucleus to the periphery. After
The organisms could be detected in mononuclear cells as early as 2 days post-incubation. Initially the organisms appeared as small and monomorphic bodies which changed into polymorphic bodies by the fourth day post-incubation (Figures 2 and 3 ).

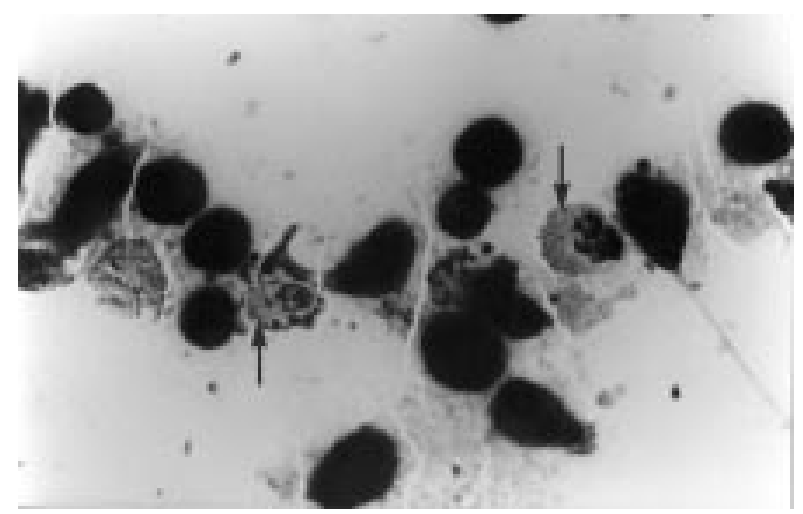

Figure 2 - Equine mononuclear cells at day 4 post incubation showing polymorphic bodies (è) -Wrights-Giemsa stain x 1000.

five days of incubation most of the host cells had disintegrated and several bodies could be seen in the extracellular space (Figure 5 ).

\section{DISCUSSION}

The morphological appearance of the organisms both in peripheral blood smears and in culture conformed to those originally reported by Ristic and Huxsoll ${ }^{16}$. In the present investigation it was noted that blood smears from the majority of animals tested were negative; only becoming positive after culture. These results suggest that parasitaemias in the originally negative animals were too low to be detected by the usual blood smear 


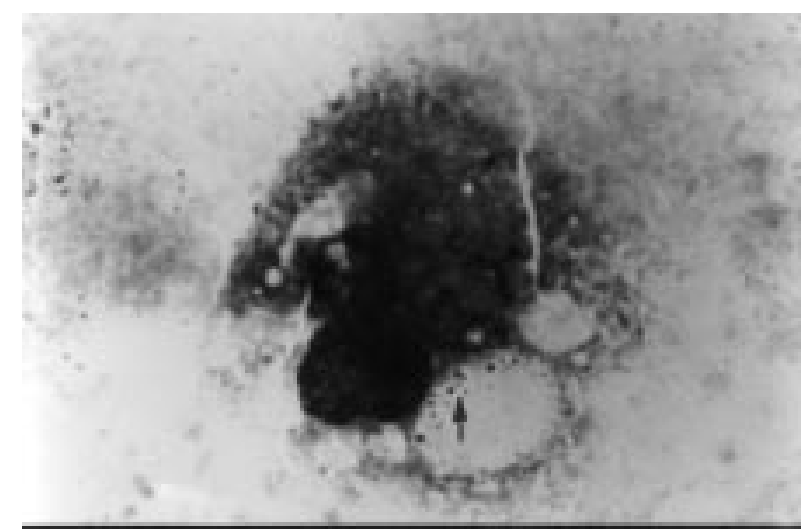

Figure 3 - Caprine mononuclear cell at day 4 post incubation showing polymorphic bodies intra and extracellulary (è) - WrightsGiemsa stain x 1000.

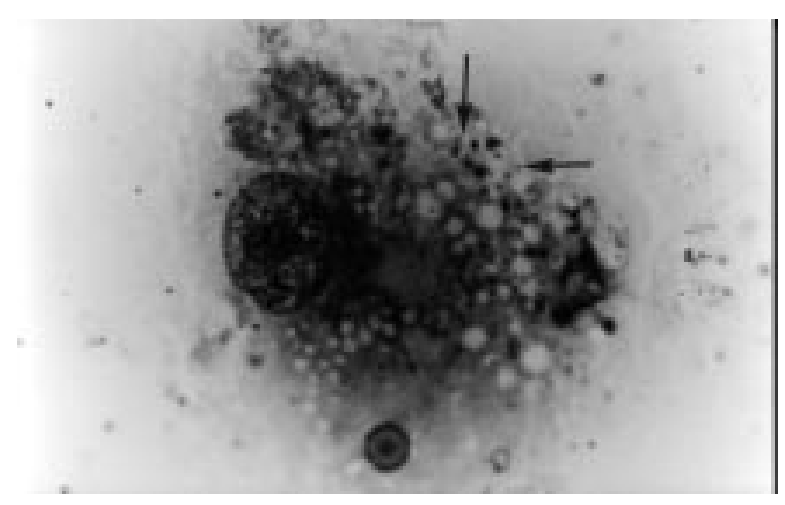

Figure 4 - Canine mononuclear cell at day 4 post incubation showing polymorphic cellular inclusions (è) - Wrights-Giemsa stain $\times 1000$.

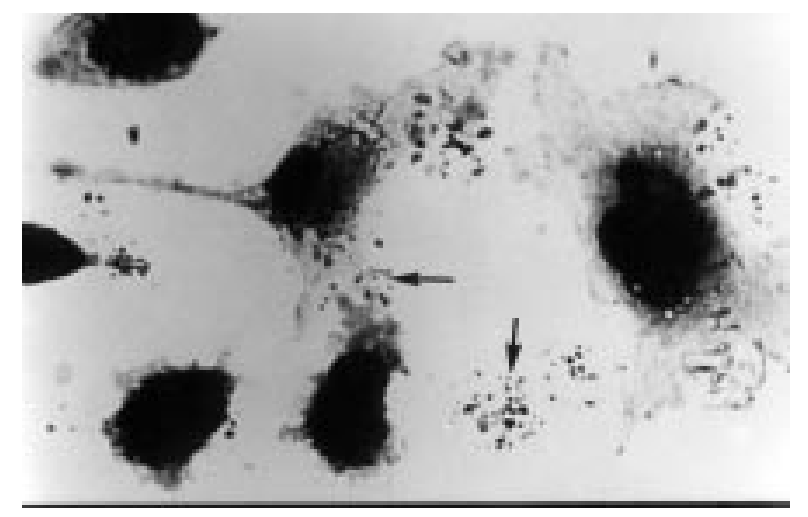

Figure 5 - Bovine mononuclear cells at day 5 post incubation showing several extracellular polymorphic bodies (è) amongst host cell debris Wrights-Giemsa x 1000.

techniques. These observations support those of Dawson et $a^{6}$. In addition Carmichael and Fiennes ${ }^{3}$ and Carter et $a A^{4}$ reported that in low parasitaemias, small ehrlichial bodies and azurophilic granules could be confused with each other, thus contributing to the difficulty in microscopic diagnosis using blood smears. The present results show that cell culture amplifies the numbers of ehrlichial bodies in a reasonably short time and do not reveal the species identity of the ehrlichial organisms. However, these results suggest that Ehrlichia may be widespread in many animal species in
Trinidad. Several species of Ehrlichia are known to exist ${ }^{16}$; being transmitted by various species of ticks present in a particular locality. In Trinidad and Tobago tick genera which have been reported include Amblyomma, Anocentor, Boophilus, Haemaphysalis, Ixodes and Rhipicephalus ${ }^{7}$. Although ticks may cross host species, the question whether Ehrlichia can cross host species remains to be resolved. The present results have shown that many apparently healthy animals may be carriers of Ehrlichia and that these asymptomatic cases can be detected by a relatively simple culture technique.

\section{ACKNOWLEDGEMENTS}

The authors wish to thank Mrs. T. Pierre, Ms. P. Seemungal and Mr. D. Superville for technical assistance and Ms. C. Gall for typing the manuscript.

\section{REFERENCES}

1. Belongia EA, Reed, KD, Mitchell PD, Kolbert CP, Persing DH, Gill JS, Kazmierczak JJ. Prevalence of granulocytic Ehrlichia infection among white-tailed deer in Wisconsin. Journal of Clinical Microbiology 35: 1465 - 1468, 1997.
2. Benjamin MM. Outline of Veterinary Clinical Pathology, $3^{\text {rd }}$ edition lowa State University Press, Ames, lowa, 1978.

3. Carmichael J, Fiennes RNTW. Rickettsia infection in dogs. Veterinary Record 54: 3 - 4, 1942. 
4. Carter GB, Seamer J, Snape, T. Diagnosis of canine tropical pancytopenia (Ehrlichia canis infection) by immunofluorescence. Research Veterinary Science 12: 318- 322, 1971.

5. Chen SM, Yu X-J, Popov VL, Westerman EL, Hamilton FG, Walker $\mathrm{DH}$. Genetic and antigenic diversity of Ehrlichia chaffeensis: Comparative analysis of a novel human strain from Oklahoma and previously isolated strains. Journal of Infectious Diseases 175: 856 - 863, 1997.

6. Dawson JE, Anderson BE, Fishbein DB, Sanhez JL, Goldsmith $\mathrm{CS}$, Wilson $\mathrm{KH}$, Duntley CW. Isolation and characterization of Ehrlichia sp. from a patient diagnosed with human ehrlichiosis. Journal of Clinical Microbiology 29: 2741- 2745, 1991.

7. Dindial P. Studies in the life cycle and seasonal incidence of Boophilus microplus (Canestrini, 1888) in Trinidad and Tobago. M.Sc. Thesis. The University of the West Indies. Saint Augustine, 1977.

8. Dumber JS, Asanovich KM, Bakken JS, Richter PS, Kimsey R, Madgan JE. Serological cross reactions among Ehrlichia equi, Ehrlichia phagocytophila and human granulocytic Ehrlichia. Journal of Clinical Microbiology 33: 1098-1103, 1995.

9. Engvall EO, Pettersson B, Persson M, Artusson K, Johansson KE. A 16S rRNA-based PCR assay for detection and identification of granulocytic Ehrlichia species in dogs, horses, and cattle. Journal of Clinical Microbiology 34: 2170- 2174, 1996.

10. Kakoma I, Hansen RD, Anderson BE, Hanley TA, Sims KG, Liu L, Bellamy C, Long MT, Baek BK. Cellular, molecular, and immunological characterization of the etiological agent of atypical canine ehrlichiosis. Journal of Clinical Microbiology 32: 170-175, 1994.

11. LHuxsoll DL, Hinderbrandt PK, Nims RM, Walker JS. Tropical canine pancytopenia. Journal of the American Veterinary Medical Association. 157: 1627-1632, 1970.

12. Murphy GL, Ewing SA, Whitworth LC, Fox JC, Kokan AA. A molecular and serological survey of Ehrlichia canis, E. chaffeensis, and E. ewingii in dogs and ticks from Oklahoma. Veterinary Parasitology 79: 325- 339, 1998.

13. Nyindo MBA, Holland CJ, Kakoma I. Current status of the in vitro cultivation of Ehrlichia. In: Williams JC, Kakoma I (eds) Ehrlichiosis, Kluwer Academic Publishers, p. 9- 21, 1990.

14. Nyindo MBA, Ristic M, Huxsoll DL, Smith AR. Tropical canine pancytopenia: in vitro cultivation of the causative agent Ehrlichia canis. American Journal of Veterinary Research 32: 1651-1658, 1971.

15. Ristic M, Huxsoll DL, Weisiger RM, Hilderbrandt PK, Nyindo MBA. Serological diagnosis of tropical canine pancytopenia by indirect fluorescence. Infection and Immunity 6: 226- 231, 1972.

16. Ristic M, Huxsoll DL. Tribe II Ehrlichiae. In: Krieg NR, Holt JG (eds) Bergey's manual of systematic bacteriology. The Williams and Wilkins Co, Baltimore, Vol I, p. 704-709, 1984.

17. Stephenson EH, Osterman JV. Canine peritoneal macrophages: cultivation and infection with Ehrlichia canis. American Journal of Veterinary Research 38: 1815-1819, 1977. 